\title{
[Regular Paper] \\ Phenol Transfer through Third Phase for Phenyl Benzoate Formation in Modified Parallel Flow Micro Reactor
}

\author{
Hiroshi YAMADA*, Takehiro SEngokU, and Tomohiko TAGAwA \\ Dept. of Chemical and Biological Engineering, Graduate School of Engineering, Nagoya University, \\ Furo-cho, Chikusa-ku, Nagoya 464-8603, JAPAN
}

(Received March 30, 2016)

\begin{abstract}
High mass transfer rate is one of the advantages of the micro reactor. Phenyl benzoate formation from benzoyl chloride and phenol was carried out in a micro reactor with a rectangular cross section micro reactor with three rounded channels which acted as stabilizers for parallel flow. Flow dynamics were very important for this reaction as phenyl benzoate and benzoyl chloride are easily hydrolyzed. The third phase contained phase transfer catalyst which was not soluble in the aqueous or organic phases. The third phase was present at the organic phase aqueous phase interface and formed a barrier for separating the aqueous and organic solutions. To maintain high selectivity for phenyl benzoate, parallel flow was required. Aqueous and organic solution flow rates were varied and flow dynamics in the micro channel was observed with a microscope. Low organic solution flow rate formed parallel flow. Reaction was carried out in the parallel flow condition. Phenol mass transfer through the third phase was the rate controlling step. To increase the main reaction rate, phenol was dissolved in both the organic and aqueous solutions. Selectivity was increased under that condition. Reaction rate in the micro reactor was higher than reaction rate in the conventional stirring batch reactor.
\end{abstract}

Keywords

Micro reactor, Flow dynamics, Mass transfer, Phase transfer catalyst, Phenyl benzoate, Reaction rate

\section{Introduction}

The micro reactor is a type of flow reactor incorporating a flow channel narrower than $500 \mu \mathrm{m}$. The micro reactor has been widely adopted because of its advantages. The reactor allows accurate control of the reaction temperature and flow dynamics because the reactor volume is small. The micro reactor is also characterized by high mass transfer rate because the high surface area to volume ratio promotes mass transfer through the phase interface. For example, mass transfer between two phases formed by two immiscible solvents greatly affects the reaction efficiency. All these characteristics increase the productivity of the micro reactor. A micro reactor is often based on a micro capillary tube ${ }^{1), 2)}$. One liquid component is passed as slugs through the continuous phase formed by the other liquid. Circulation flow near the interface increases the mass transfer between these liquids ${ }^{3), 4)}$. Consequently, the micro reactor achieves superior per-

This paper was presented at the Nagoya Convention of JPI (45th Petroleum-Petrochemical Symposium of Jpn. Petrol. Inst.), Nagoya, Japan, Nov. 5-6, 2015.

DOI: dx.doi.org/10.1627/jpi.59.204

* To whom correspondence should be addressed.

* E-mail: yamada@nuce.nagoya-u.ac.jp formance compared to the conventional mixing tank reactor ${ }^{5)}$.

Reactions involving easily hydrolyzed product or reactant require precise control of contact with water. To overcome this problem, we have proposed the third phase system. The third phase consists of a liquid which is immiscible with both the organic and aqueous phases, and operates as a phase transfer catalyst. Generally, the phase transfer catalyst transfers reactant from one liquid phase to the other liquid phase. In some cases, the phase transfer catalyst transfers reactants from the aqueous and organic phases onto the catalyst phase. The third phase mainly consists of the phase transfer catalyst with small amounts of organic solution and water. Figure 1 shows an example ${ }^{6)}$ for the reaction of benzoyl chloride and phenol to form phenyl benzoate. This is a typical esterification reaction with acyl chloride and alcohol in the presence of

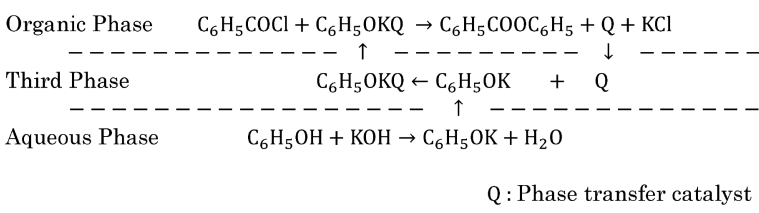

Q: Phase transfer catalyst 


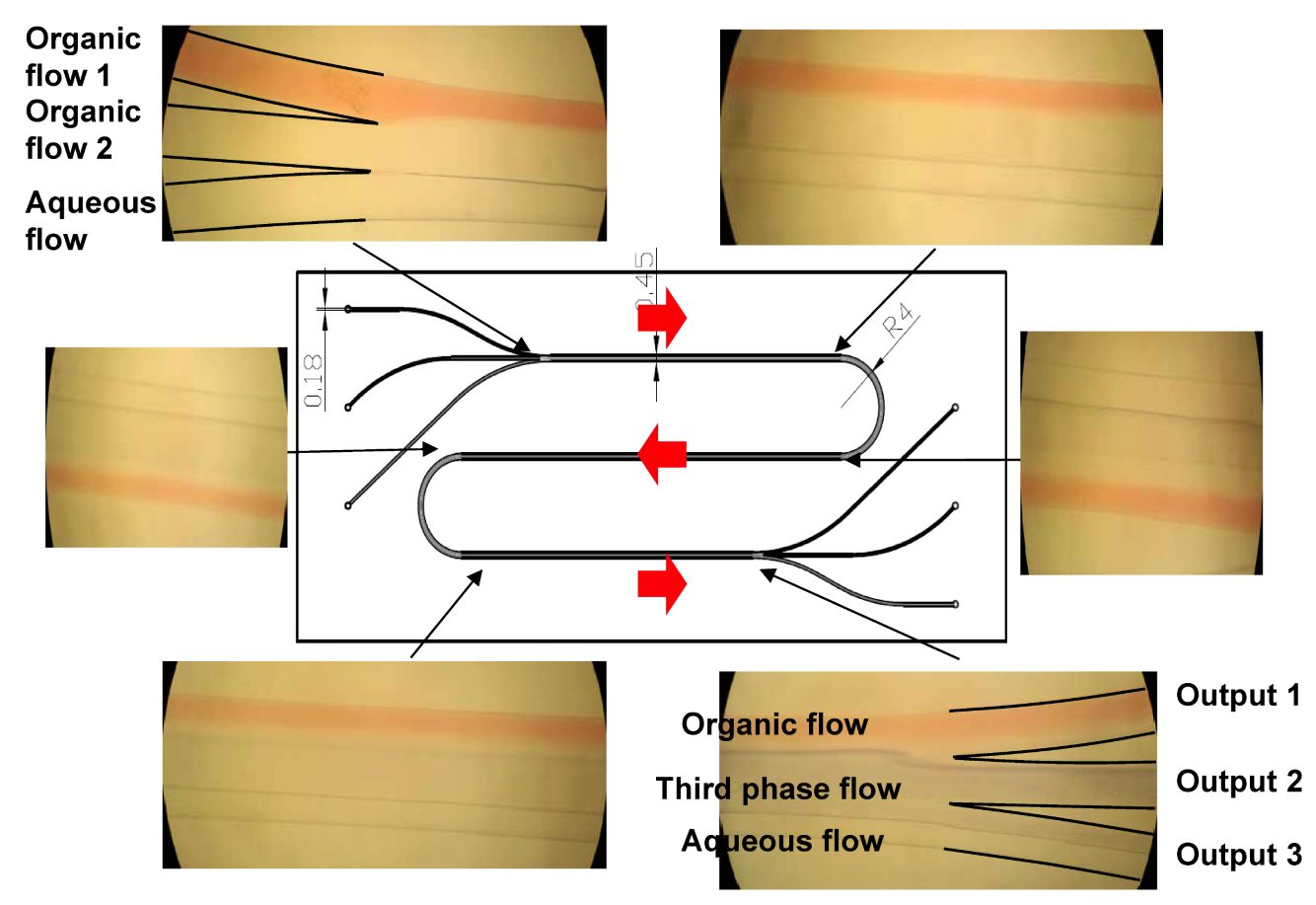

Fig. 2 Three Phase Parallel Flow in the Micro Reactor

potassium. The present study used this model reaction to investigate the third phase system. In the system, phenol reacted with potassium hydroxide to form potassium phenoxide, which was transferred to the organic phase through the third phase by the phase transfer catalyst. Benzoyl chloride and potassium phenoxide reacted to form phenyl benzoate in the organic phase. The third phase operated not only as the phase transfer catalyst but also as a barrier between the organic phase and aqueous phase to prevent hydrolysis of the reactant and product. The third phase could not form a good barrier for this reaction in the slug flow micro reactor, as disturbance of the third phase would result in hydrolysis. Therefore, we proposed the use of three phase parallel flow to solve this problem.

The aqueous solution, third phase, and organic solution are passed through the reactor in a laminar flow, so that the liquids remain separated in the three phase parallel flow. Maintenance of the parallel flow allows collection of the three phases through separate outlets for each liquid. Consequently, no separation equipment is needed in this system. Parallel flow only remains stable within a limited flow rate range. However, guide line structures in the micro channel are effective for stabilizing parallel flow ${ }^{7)}$ and can stabilize three phase parallel flow of aqueous solution/alcohol/alcohol phases $^{8)}$.

Liquid phase reaction in the micro reactor is often carried out under slug flow conditions. Clearly, parallel flow has some advantages, such as for preventing hydrolysis and separating reactants and products. The present study investigated the characteristics of three phase parallel flow formation and mass transfer.

\section{Experimental}

\section{1. Batch Reactor}

Phenyl benzoate formation from benzoyl chloride and phenol was carried out as the model reaction. Benzoyl chloride and polyethylene glycol (molecular weight 400) were dissolved in $100 \mathrm{~cm}^{3}$ of toluene. Potassium hydroxide and phenol were dissolved in $100 \mathrm{~cm}^{3}$ of water. These solutions were placed into the stirring tank of a batch reactor and maintained at $303 \mathrm{~K}$. The potassium hydroxide concentration was $30 \%$ of the saturated concentration. Potassium hydroxide inhibits the dissolution of polyethylene glycol into water. Phenol introduces some water into the organic solution and polyethylene glycol is dissolved in this water. This polyethylene glycol cannot dissolve into both the organic solution and the aqueous solution, thus forming the third phase $\mathrm{e}^{9), 10)}$. In some experiments, phenol was dissolved in both toluene and water.

All chemicals were purchased from Wako Pure Chemical Industries, Ltd. Polyethylene was Wako 1st grade and the others reagents were Wako special grade. No chemicals were further purified.

\section{2. Micro Reactor}

The micro reactor was designed by us and manufactured by the Institute of Microchemical Technology Co., Ltd. Figure 2 shows the design drawing of the micro reactor chip. Flow dynamics will be discussed 


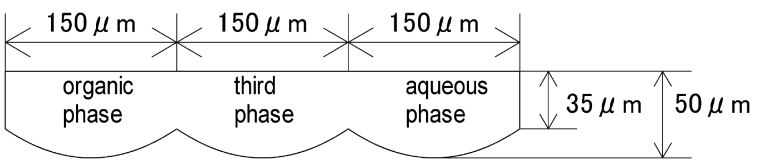

Fig. 3 Channel Cross Section

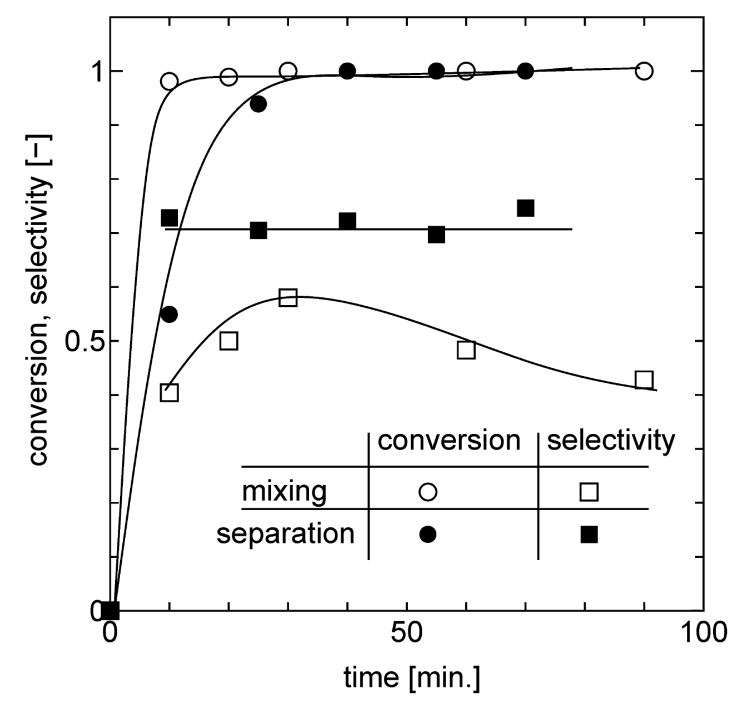

$C_{\mathrm{bc}, \text { org }}: 0.1 \mathrm{M}, C_{\text {peg,org }}: 0.1 \mathrm{M}, C_{\text {phe,aq }}: 0.5 \mathrm{M}$.

Fig. 4 Comparison of Mixing Reactor and Separation Reactor

in section 3. 2. The micro reactor chip incorporates three inlets and three outlets. After the merging point, the liquids are passed into a channel in the reactor. The reaction starts after this point, proceeds with the liquid flow, and ends at the separation point. The channel length between the merging point and the separation point is $120 \mathrm{~mm}$ with two turns. Figure 3 shows the channel cross section. The bottom of the channel consists of three rounded faces, which act as guide structures to stabilize the three phase parallel flow.

Benzoyl chloride and polyethylene glycol (molecular weight 400) were dissolved in toluene to form organic solution 1. Polyethylene glycol was dissolved in toluene to form organic solution 2 . The flow rates of organic solutions 1 and 2 were same in all experiments. Phenol was added to organic solution 2 in some experiments. Potassium hydroxide and phenol were dissolved in water to form the aqueous solution. Potassium hydroxide concentration was $30 \%$ of the saturated concentration. Organic solution 1, organic solution 2, and aqueous solution were supplied to the three inlets as shown in Figs. 2 and 3. Three liquids flow rates were the same in each other in all experiments except as shown in Fig. 6.

\section{3. Analysis Method}

Organic solution was collected and analyzed by hydrogen-flame ionization detector (FID) gas chromatography using a GC-353B (GL Sciences Inc.) with

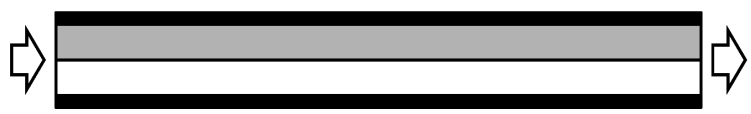

(1) Parallel flow

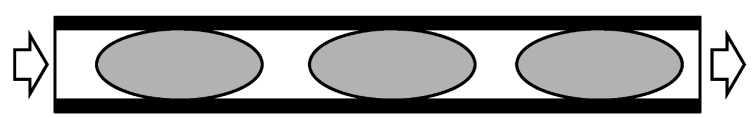

(2) Slug flow

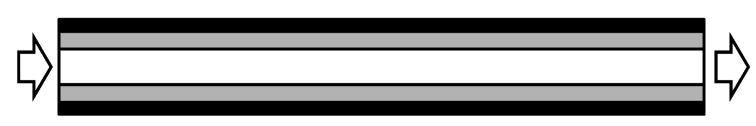

(3) Annular flow

Fig. 5 Flow Patterns

HP-5 column (Agilent Technologies) and argon carrier. Conversion was calculated from the amount of consumed benzyl chloride. Selectivity was calculated from the amounts of produced phenyl benzoate and consumed benzyl chloride.

\section{Results and Discussion}

\section{1. Effect of Phase State on Reaction in the Stirring Tank Batch Reactor}

Hydrolysis of the reactant, benzyl chloride, and the product, phenyl benzoate, will occur in the organic solution unless contact of the organic and aqueous solutions is controlled. Figure $\mathbf{4}$ compares the contact patterns in the stirring tank batch reactor. At high impeller rotation speed, $300 \mathrm{rpm}$, the organic and aqueous phases were well mixed in the mixing reactor. At low rotation speed, $30 \mathrm{rpm}$, the organic and aqueous phases were separated by the third phase in the separation reactor. However, the reaction rate was slower in the separation reactor than in the mixing reactor. Reactant mass transfer was inhibited by the third phase. On the other hand, the third phase prevented contact of the reactant, benzoyl chloride, and the product, phenyl benzoate, with water. The selectivity was higher in the separation reactor than in the mixing reactor. This result indicated that separate phase flow was required for high selectivity in the flow reactor.

\section{2. Flow Dynamics in the Micro Reactor}

Flow dynamics in the micro reactor depend on the liquid flow rates. Three flow patterns were observed in the reactor as shown in Fig. 5. Parallel flow was a laminar flow in which the liquids flowed separately. Slug flow involved flow of liquid slugs in the other liquid phase. Annular flow consisted of liquid phase flowing along the reactor wall and another liquid phase flowing in the center of the reactor channel.

Figure 6 shows the effect of liquid flow rate on the flow dynamics. Organic flow rate was the total of the flow rates of organic solution 1 and organic solution 2 . 
- 3 phase parallel flow

$\triangle$ organic laminar flow + slug in aqueous flow, also annular flow

$\square$ slug flow or annular flow depending location

$\diamond$ repeat $\Delta$ and $\square$

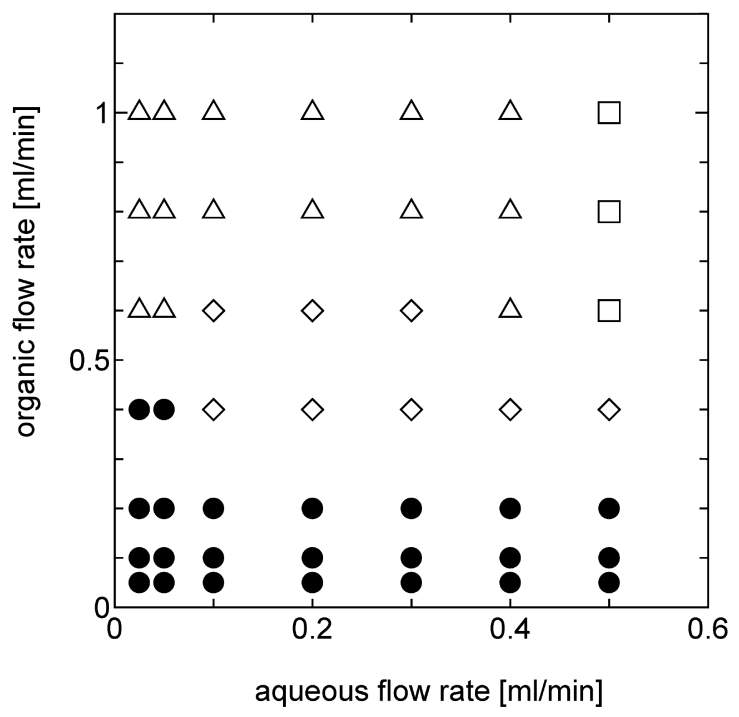

$C_{\text {bc,org1 }}: 0.1 \mathrm{M}, C_{\text {peg,org1 }}: 0.7 \mathrm{M}, C_{\text {peg,org2 }}: 0.7 \mathrm{M}, C_{\text {phe aq }}: 0.5 \mathrm{M}$.

Fig. 6 Flow State

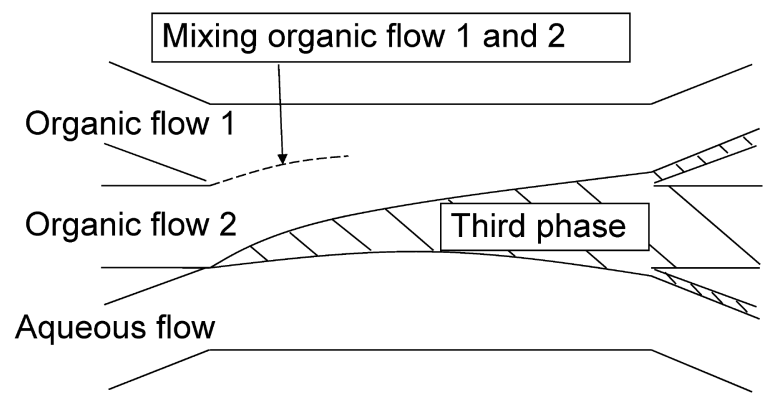

Fig. 7 Schematic Diagram of Three Phase Parallel Flow

Three phase parallel flow was obtained at low organic solution flow rates. The catalyst was dissolved in the organic phase and the third phase was formed after the organic solution and aqueous solution were contacted in the reactor, as shown in Fig. 7. Organic solution residence time was the key to the amount of third phase, because third phase formation required induction time. In contrast, flow dynamics in the micro reactor channel were unstable at high organic solution flow rates, with the flow pattern varying in position with time.

Figure 2 shows the flow dynamics of three phase parallel flow. Two organic solutions were separately passed into the reactor and contacted with the aqueous solution. Organic solution 1 contained the catalyst and benzoyl chloride and red dye. Organic solution 2 contained catalyst. The third phase was formed, seen as the pale blue solution in Fig. 2. The third phase

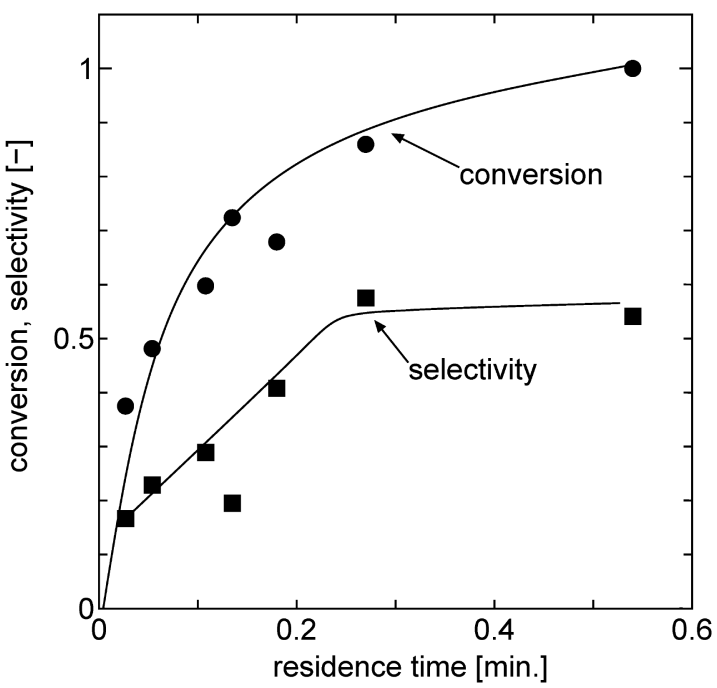

$C_{\mathrm{bc}, \text { org1 }}: 0.01 \mathrm{M}, C_{\text {peg,org1 }}: 0.7 \mathrm{M}, C_{\text {peg,org2 }}: 0.7 \mathrm{M}, C_{\text {phe,aq }}: 0.5 \mathrm{M}$.

Fig. 8 Added Phenol in Aqueous Phase

was not so defined at the input but became clearer as the liquids passed to the output. Parallel flow was maintained even in the curved channel. Organic solution, third phase, and aqueous solution passed out from outputs 1, 2, 3 respectively. Some of the third phase flowed out from outputs 1 and 3 . The third phase from outputs 1 and 3 were immiscible in the organic phase and aqueous phase, respectively, so could be separated in the collector. No aqueous solution was observed in output 1 and no organic solution was observed in output 3. Therefore, the third phase separated the organic solution and aqueous solution in the micro reactor.

\section{3. Reaction in the Micro Reactor}

Figure 8 shows the conversion and selectivity profiles with residence time. Residence time was defined as the ratio of reactor volume and volume flow rate of all liquid solutions. Conversion increased with longer residence time. Selectivity increased to 0.55 . Selectivity was lower than in the separation reactor in Fig. 3. The third phase in the micro reactor was narrower than in the batch reactor. Hydrolysis easily occurred in the micro reactor. Therefore, increase in the main reaction rate will increase the selectivity.

Phenol and toluene concentrations in the third phase flowing out from outputs 3,2, and 1 were measured and compared to the concentration profiles in the third phase with respect to residence time in Fig. 9. The horizontal axis in this figure shows the distance from the third phase aqueous phase interface, $0 \mu \mathrm{m}$, to the third phase organic phase interface, $150 \mu \mathrm{m}$. Toluene and phenol showed large concentration gradients in the third phase. Residence time had little effect on the concentration profile in the third phase. Therefore, mass transfer outside of the third phase was higher than mass transfer in the third phase. This high mass transfer resistance 


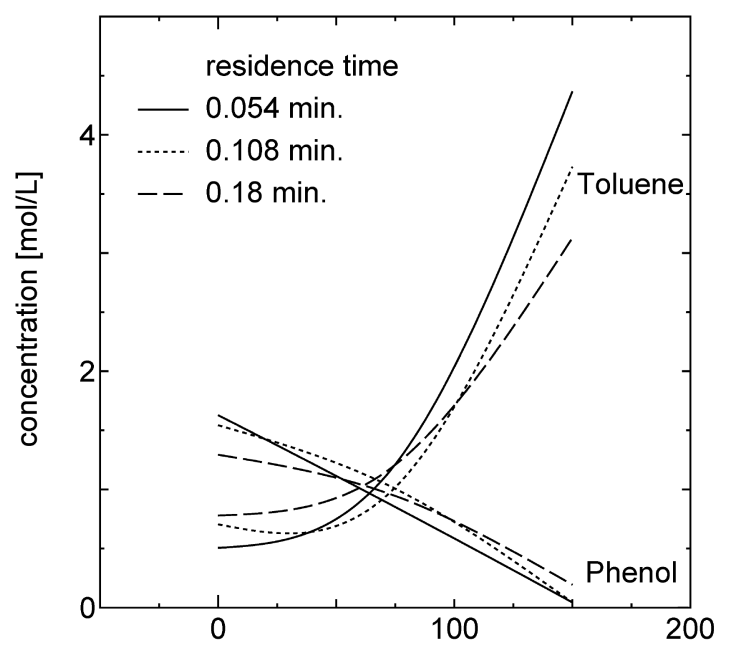

distance from third phase aqueous phase interface $[\mu \mathrm{m}]$

$C_{\mathrm{bc}, \text { org1 }}: 0 \mathrm{M}, C_{\mathrm{peg}, \text { org 1 }}: 0.4 \mathrm{M}, C_{\mathrm{peg}, \mathrm{org} 2}: 0.4 \mathrm{M}, C_{\mathrm{phe,aq}}: 0.5 \mathrm{M}$.

Fig. 9 Concentration Profile in the Third Phase

decreased the main reaction rate and the selectivity for the product.

To increase the main reaction rate, phenol was added to organic solution 2. Phenol added to the aqueous solution was dissolved and formed potassium phenoxide. In the micro reactor, phenol was extracted into the third phase and diffused across the third phase to the organic solution. The diffusion rate was slow because of the high viscosity of the third phase. This low diffusion rate resulted in low phenol concentration at the interface of the third phase and the organic solution. Consequently, the main reaction rate was low. Therefore, addition of phenol to both the aqueous solution and the organic solution increased the phenol concentration in the organic phase and should increase the main reaction rate. Figure $\mathbf{1 0}$ shows the effect of phenol addition. Selectivity was increased by addition of phenol to both the aqueous and organic solutions. Selectivity was increased with longer residence time at low residence times. Phenoxide transportation across the third phase and phenoxide formation from dissolved phenol in the organic phase resulted in higher phenoxide concentration in the organic solution. Therefore, the main reaction rate was increased under these conditions. Selectivity was decreased at residence times over $0.08 \mathrm{~min}$. The product was hydrolyzed with water in the third phase.

To increase the main reaction rate, phenol concentration was doubled. Figure 11 shows the reaction results. Reaction rate and maximum selectivity were increased. However, the hydrolysis rate was also increased, so maximum yield was reduced. Therefore, suppression of the hydrolysis rate is required to achieve higher yield.

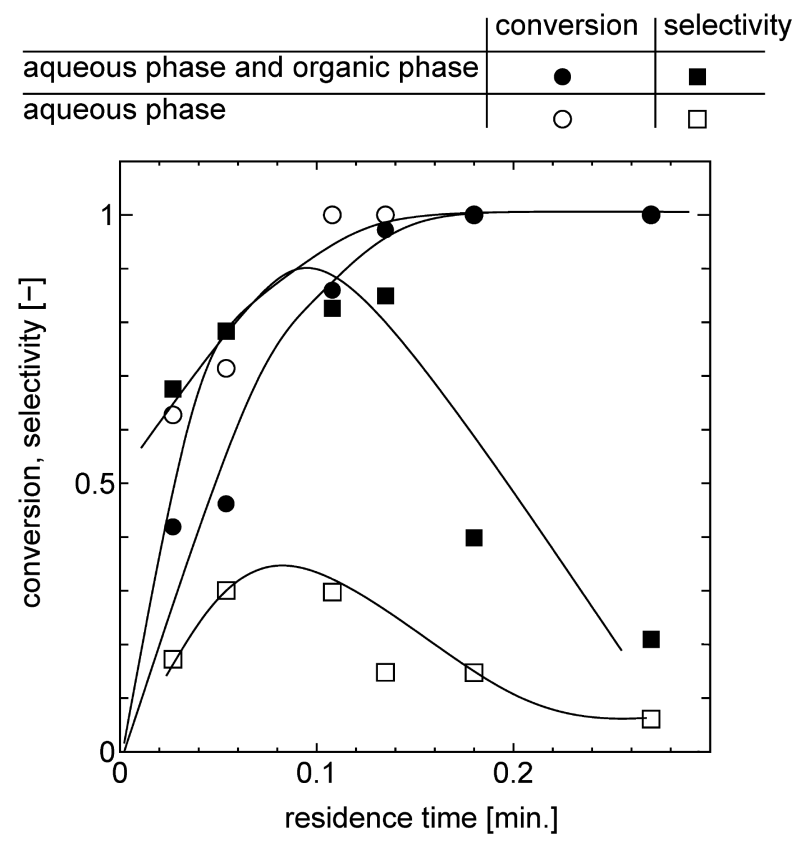

$C_{\mathrm{bc}, \mathrm{org} 1}: 0.05 \mathrm{M}, C_{\mathrm{peg}, \mathrm{org} 1}: 0.4 \mathrm{M}, C_{\mathrm{peg}, \mathrm{org} 2}: 0.4 \mathrm{M}$.

(aqueous phase and organic phase) $C_{\text {phe,org1 }}: 0.25 \mathrm{M}, C_{\text {phe,aq }}: 0.25 \mathrm{M}$. (aqueous phase) $C_{\text {phe,org1 }}: 0 \mathrm{M}, C_{\text {phe,aq }}: 0.5 \mathrm{M}$.

Fig. 10 Comparison of Phenol Addition Phase

\begin{tabular}{c|c|c} 
& conversion & selectivity \\
\hline $0.25 \mathrm{M}$ & $\bullet$ & $\square$ \\
\hline $0.50 \mathrm{M}$ & $\circ$ & $\square$
\end{tabular}

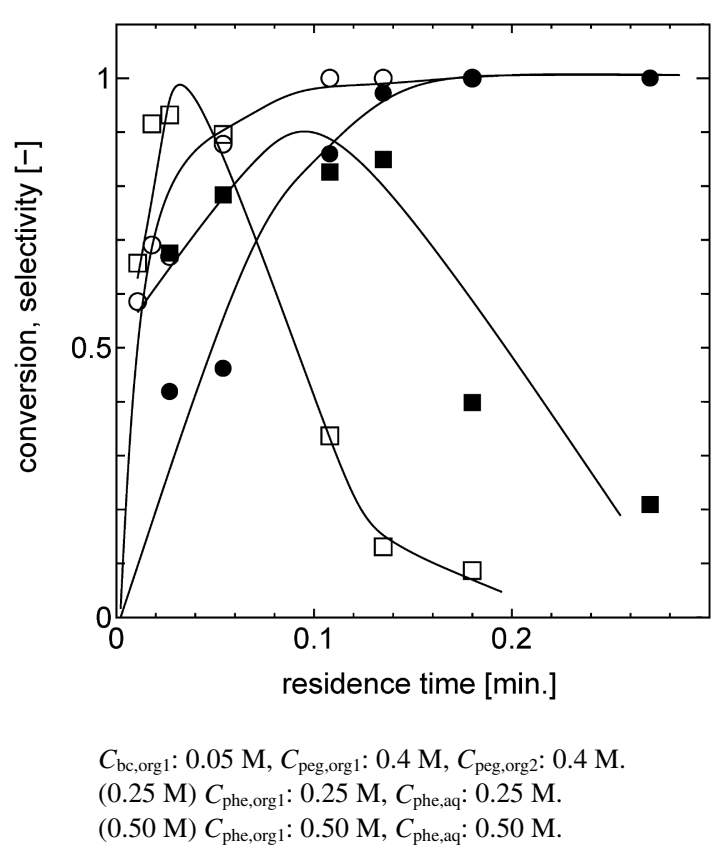

Fig. 11 Phenol Concentration Effect

\section{4. Reaction Rates in the Micro Reactor and the Conventional Batch Reactor}

Figure 12 shows the experimental results of the 


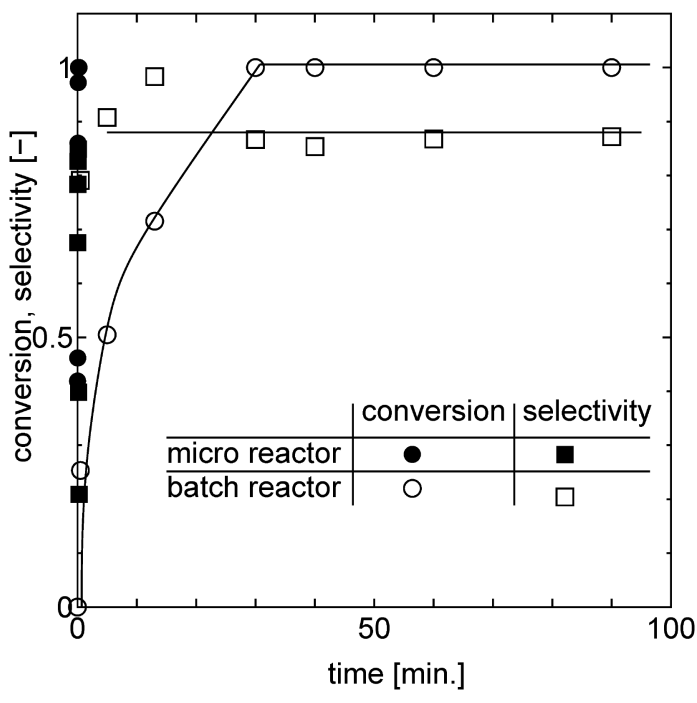

(micro) $C_{\mathrm{bc}, \text { org1 }}: 0.05 \mathrm{M}, C_{\mathrm{peg}, \text { org1 }}: 0.4 \mathrm{M}, C_{\mathrm{peg}, \text { org2 }}: 0.4 \mathrm{M}, C_{\mathrm{phe,org} 2}$ : $0.25 \mathrm{M}, \mathrm{C}_{\text {phe,aq }}: 0.25 \mathrm{M}$.

(batch) $C_{\mathrm{bc}, \text { org: }}: 0.025 \mathrm{M}, C_{\mathrm{peg}, \text { org }}: 0.1 \mathrm{M}, C_{\mathrm{phe}, \mathrm{org}}: 0.25 \mathrm{M}, C_{\mathrm{phe}, \mathrm{aq}}: 0.25 \mathrm{M}$, $80 \mathrm{rpm}$.

Fig. 12 Comparison of Micro Reactor and Batch Reactor

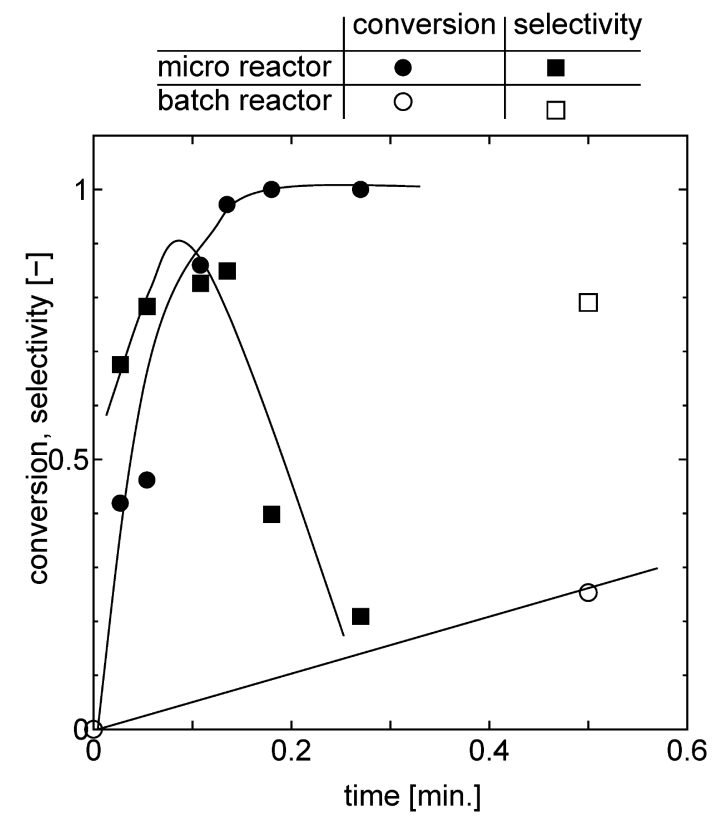

Fig. 13 Comparison of Micro Reactor and Batch Reactor

micro reactor and conventional batch reactor. Reaction time before $0.5 \mathrm{~min}$ is shown in Fig. 13. Selectivity in the micro reactor was decreased after conversion reached 1. Product hydrolysis decreased the selectivity. Selectivity in the batch reactor was stable. The third phase in the batch reactor was approximately three times thicker than the third phase in the micro reactor. Water did not diffuse rapidly through the third phase.
Product hydrolysis did not occurred after conversion reached 1. On the other hand, the reaction rate in micro reactor was very high. Mass transfer rate was enhanced in the micro reactor.

\section{Conclusion}

Phenyl benzoate formation from benzoyl chloride and phenol was carried out in the micro reactor and stirring tank batch reactor. Prevention of contact of water with the organic phase is important, because benzoyl chloride and phenyl benzoate are easily hydrolyzed. The third phase containing phase transfer catalyst prevented the contact of water with the organic phase. Maintaining phase separation using low stirring rate in the batch reactor or parallel flow in the micro reactor was important. Parallel flow was observed when the organic solution flow rate was low. However, parallel flow in the micro reactor resulted in low reaction rate because phenol transfer rate through the third phase was low. Phenol addition to the organic phase was effective to increase the reaction rate. Stabilizing the parallel flow in the micro channel and higher phenol concentration in the organic solution were important in the micro reactor.

\begin{tabular}{|c|c|c|}
\hline \multicolumn{3}{|c|}{ Nomenclatures } \\
\hline$C$ & : concentration & {$[\mathrm{mol} / \mathrm{L}]$} \\
\hline \multicolumn{3}{|c|}{$<$ Subscripts $>$} \\
\hline $\mathrm{bc}$ & : benzyl chloride & \\
\hline peg & : polyethylene glycol & \\
\hline phe & : phenol & \\
\hline aq & : aqueous solution & \\
\hline org & : organic solution in stirred tank batch reactor & \\
\hline org1 & : organic solution 1 in micro reactor & \\
\hline org2 & : organic solution 2 in micro reactor & \\
\hline
\end{tabular}

\section{References}

1) Aljbour, S., Tagawa, T., Yamada, H., J. Chem. Eng. Jpn., 42, 400 (2009).

2) Biswas, K. G., Patra, R., Das, G, Ray, S., Basu, J. K., Chem. Eng. J., 262, 436 (2015).

3) Ghaini, A., Mescher, A., Agar, A. W., Chem. Eng. Sci., 66, 1168 (2011).

4) Burns, J. R., Ramshaw, C., Lab Chip, 1, 10 (2001).

5) Aljbour, S., Yamada, H., Tagawa, T., Chem. Eng. Process., 48, 1167 (2009).

6) Ido, T., Shimizu, T., Jin, G., Goto, S., Kagaku Kogaku Ronbunshu, 29, 534 (2003).

7) Tagawa, T., Aljbour, S., Matouq, M., Yamada, H., Chem. Eng. Sci., 62, 5123 (2007).

8) Matouq, M., Al-Anber, Z., Tagawa, T., Aljbour, S., Yamada, H., J. Appl. Sci., 8, 601 (2008).

9) Ido, T., Saiki, M., Goto, S., Kagaku Kogaku Ronbunshu, 14, 403 (1989).

10) Ido, T., Yoshikawa, T., Jin, G., Goto, S., Kagaku Kogaku Ronbunshu, 28, 88 (2002). 
要旨

マイクロリアクターにおける安息香酸フェニル生成のための第三相中でのフェノールの物質移動

山田 博史, 仙石 雄大, 田川 智彦

名古屋大学大学院工学研究科化学生物工学専攻, 464-8603 名古屋市千種区不老町

マイクロリアクター中での物質移動研究のモデル反応として 塩化ベンゾイルとフェノールからの安息香酸フェニル生成反応 を行った。流路は断面が矩形 (くけい) で底面が三つの曲面か らなっている。この曲面は並行流を安定化させる役割がある。 塩化ベンゾイルと安息香酸フェニルは加水分解を起こすため, 水相と接しないようにしなくてはならない。そのために相間移 動触媒である第三相を有機相と水相の間に生成させ，水が有機 相中の原料や生成物と接しないようにした。まず，有機溶媒と
水溶液の流量が反応器内の流動状態に与える影響について検討 した。有機溶媒の流量が低いとき反応器内は有機-第三相-水の 並行流となった。この並行流の状態で反応実験を行った。第三 相中のフェノールの拡散が反応の律速段階であることが分かっ た。主反応の速度を上昇させるためにフェノールを水だけでな く有機溶媒にも加えた。これにより選択率が向上した。マイク ロリアクターでの反応速度を従来の擋找相反応器と比較したと ころ, 反応速度の向上がみられた。 